\title{
Technology Transfer Plan
}

\author{
Final Report \\ December 31, 1998
}

Work Performed Under Contract No.: DE-FC21-95MC30081

\author{
For \\ U.S. Department of Energy \\ Office of Fossil Energy \\ Federal Energy Technology Center \\ P.O. Box 880 \\ Morgantown, West Virginia 26507-0880
}

By

BPF Incorporated

1555 Valwood Parkway

Carrollton, Texas 75006 


\section{Disclaimer}

This report was prepared as an account of work sponsored by an agency of the United States Government. Neither the United States Government nor any agency thereof, nor any of their employees, makes any warranty, express or implied, or assumes any legal liability or responsibility for the accuracy, completeness, or usefulness of any information, apparatus, product, or process disclosed, or represents that its use would not infringe privately owed rights. Reference herein to any specific commercial product, process, or service by trade name, trademark, manufacturer, or otherwise does not necessarily constitute or imply its endorsement, recommendation, or favoring by the United States Government or any agency thereof. The views and opinions of authors expressed herein do not necessarily state or reflect those of the United States Government or any agency thereof. 


\section{DISCLAIMER}

Portions of this document may be illegible electronic image products. Images are produced from the best available original document. 


\section{BPF, Incorporated \\ Technology Transfer Plan \\ DOE Cooperative Agreement \#DE-FC21-95MT30081}

\section{Introduction}

This plan is provided to DOE in order to satisfy Task 16 of the Cooperative Agreèment DEFC21-95MT30081.

The plan outlines the approach BPF will use to transfer its knowledge on the treatimenti and underground disposal of NORM waste associated with oil and gas production to poterifal regulators, and other stakeholders. It implements a broad range of communication vehicles and organizational avenues in order to reach the widest audience.

\section{Background}

BPF developed the concept of a mobile, on-site NORM remediation and disposal process in late 1993. Working with Conoco and receiving encouragement from the Department of Energy, Metarie Office, and the Texas Railroad Commission, the corporation conducted extensive feasibility studies on an on-site disposal concept.

In May 1994, the Department of Energy issued a solicitation for cooperative agreement proposal for, "Development and Testing of a Method for Treatment and Underground Disposal of Naturally Occurring Radioactive Materials (NORM)". BPF submitted a proposal to the solicitation in July 1994, and was awarded a cooperative agreement in September 1995.

BPF proposed and believed that proven equipment and technology could be incorporated in to a mobile system. The system would allow BPF to demonstrate an environmentally sound and commercially affordable method for treatment and underground disposal of NORM. The key stop in the BPF process incorporates injection of the dissolved radioactive materials into a water injection or disposal well.

Disposal costs in the BPF proposal of July 1995 were projected to range from $\$ 1000$ to $\$ 5000$ per cubic yard. The process included four separate steps.

(1) De-oiling

(2) Volume Reduction

(3) Chemical Dissolution of the Radium

(4) Injection

Bench-scale testing completed in April 1997 demonstrated the viability of the BPF process and was used as the basis for the design of pilot-scale equipment with a throughput capability of $1000 \mathrm{lbs} / \mathrm{hr}$. 
Pilot-scale testing was completed in June 1998, providing a solid basis for commercial operations.

Technology transfer commenced with submission of the proposal in July 1995, and will continue into the future.

\section{Technology Transfer Avenues}

BPF will employ, as funds are available, and has used, a range of avenues for the transfer of the technology developed under the Cooperative Agreement. A summary description is provided below:

Papers and articles on Bench-Scale and Pilot-Scale results

- Professional societies and topical conferences

- Professional journals

- Mailings to oil and gas professionals

- Exhibit booths

Promotional material on the process, its benefits, and its cost

- Posting on the BPF worldwide website

- Mailings to oil and gas professionals

- Articles and advertisement in oil and gas trade magazines and journals

Hands-on experience on the process

- Summer student prograrn, providing jobs for university undergraduates working at clean-up sites and in the Duncanville, TX laboratory

NORM training

- Production of a computer-based training module that is planned to be available to the public in late 1998

Petroleum Technology Transfer Council

- Prepare and present a workshop on NORM remediation process to be held in Duncanville, TX

Site unique process evaluation

- BPF will contact and request samples from companies. The samples will be used to conduct bench-scale process evaluation in the Duncanville, TX office. The results will be provided to the companies in the form of a cost estimate for employing the $\mathrm{BPF}$ process. Each customer will be briefed in detail on the process as part of the cost estimate presentation. 


\section{Previous Technology Transfer}

BPF has been conducting technology transfer since the award of the Cooperative Agreement in September 1995. A list of the activities completed to date is included in Appendix A.

\section{Future Technology Transfer}

BPF will carry out all the activities outlined above. The final activity under the auspices of the Cooperative Agreement will be the paper presented at the 5th Annual IPEC Conference in October 1998. 


\section{Technical Papers and Articles on Bench-Scale and Pilot-Scale Test Results}

Paper, Results from Bench-Scale Testing of a Mobile NORM Treatment and Disposal System, SPA E\&P Environmental Conference, 1996

Paper and Exhibit, Results from Bench-Scale Testing of a Mobile NORM Treatment and Disposal System, 3rd International Petroleum Environmental Conference, 24-27 Sep 96, Albuquerque NM

Exhibit, Mobile Treatment/Disposal System for NORM Wastes Generated in Oil/Gas Production, Society of Petroleum Engineers/U.S. Environmental Protection Agency 1997 Exploration and Production Environmental Conference, 3-5 Mar 97, Dallas TX

Paper, Results of Bench-Scale Testing of a Mobile On-Site NORM Treatment System in Texas and New Mexico, U.S. Department of Energy Federal Energy Technology Center Natural Gas Conference, 24-27 Mar 97, Houston TX

Mailing, BPF Company Profile, mailed to 23 professional local, national, and international industry contacts, mailed May 97

Mailing, BPF is Prepared and Qualified to Provide and Manage Environmental Surveys and Environmental Remediation, mailed to 94 professional national and international industry contacts, mailed Apr 97

Slide Presentation, Bench-Scale Tesing of a Mobile NORM Treatment and Disposal System, U.S. Department of Energy-Contractor Review Meeting, 16-20 Jun 97, Houston TX

Slide Presentation, Bench-Scale Testing of a Mobile NORM Treatment and Disposal System, U.S. Department of the Interior, Minerals Management Service Regional Operations Technology Assessment Committee Meeting, 20 Aug 97, Camarillo CA

Paper, Initial Results from the BPF Mobile NORM Treatment and Disposal System Pilot-Scale Development, 4th International Petroleum Environmental Conference, 9-12 Sep 97, San Antonio TX

Mailing, BPF Newsletter, Volume 1, Issue 1, October 1997, Managing NORM in the Oil and Gas Industry, mailed to 416 oil and gas companies listed in the 27th Edition 1997 Oil and Gas Directory, The Geophysical Directory, Inc. (Publisher), mailed Oct 97

Mailing, BPF Newsletter, Volume 1, Issue 1, October 1997, Managing NORM in the Oil and Gas Industry, mailed to 237 registered attendees and 49 speakers, moderators, and exhibitors of the U.S. EPA Environmental Clean Up Conference, South Central Marketplace, 13-14 Nov 97, New Orleans, LA, mailed Nov 97 
Mailing, BPF Newsletter, Volume 1, Issue 1, October 1997, Managing NORM in the Oil and Gas Industry, mailed to 339 registered attendees of the Interstate Oil and Gas Compact Commission 1997 Annual Meeting, 6-8 Dec 97, Santa Fe NM, mailed Dec 97

Mailing, Is Your Site Safe? Treatment and On-Site Disposal of Radioactive Soils, Jan 98, mailed to 4 petroleum industry contacts, rnailed Jan 98

Mailing, Initial Results from the BPF Mobile NORM Treatment and Disposal System Pilot-Scale Development, Sep 97; Is Your Site Safe? Treatment and On-Site Disposal of Radioactive Soils, Jan 98; mailed in accordance with an industrial contact request, mailed 15 Jan 98

Mailing, Is Your Site Safe? Treatment and On-Site Disposal of Radioactive Soils, Jan 98, mailed to 221 personal, government, and industrial contacts, mailed 15-21 Jan 98

Mailing, Demonstration of Technologies for Cleanup of St. Louis Airport Site (SLAPS); Is Your Site Safe? Treatment and On-Site Disposal of Radioactive Soils, Jan 98; mailed in accordance with request from three United Kingdom radioactive contamination clean up corporations, mailed 20 Jan 98

Mailing, Capabilities for the Treatment and On-Site Disposal of Radioactive Soils; Demonstration of Technologies for Cleanup of St. Louis Airport Site (SLAPS); mailed in accordance with request from US DOE Rocky Flats Field Office, Golden CO, mailed 21 Jan 98

Mailing, Is Your Site Safe? Treatment and On-Site Disposal of Radioactive Soils, Jan 98; Capabilities for the Treatment and On-Site Disposal of Radioactive Soils; Demonstration of Technologies for Cleanup of St. Louis Airport Site (SLAPS); Pilot-Scale Demonstration Plan, Dec 97, Results of Bench-Scale Testing of a Mobile On-Site NORM Treatment System in Texas and New Mexico; Results from Bench-Scale Testing of a Mobile NORM Treatment and Disposal System; mailed in accordance with request from Phillips Research Center, mailed 27 Jan 98

Mailing, BPF, Incorporated Corporate Profile, Jan 98; Capabilities for the Treatment and On-site Disposal of Radioactive Soils; Is Your Site Safe? Treatment and On-Site Disposal of Radioactive Soils, Jan 98; Results from Bench-Scale Testing of a Mobile NORM Treatment and Disposal System; Results of Bench-Scale Testing of a Mobile On-Site NORM Treatment System in Texas and New Mexico; Demonstration of Technologies for Cleanup of St. Louis Airport Site (SLAPS); mailed in accordance with request from SAIC Corporation, mailed 29 Jan 98

Mailing, BPF, Incorporated Corporate Profile, 10 Feb 98; Capabilities for the Treatment and Onsite Disposal of Radioactive Soils; Is Your Site Safe? Treatment and On-Site Disposal of Radioactive Soils, Jan 98; Results from Bench-Scale Testing of a Mobile NORM Treatment and Disposal System; Results of Bench-Scale Testing of a Mobile On-Site NORM Treatment System in Texas and New Mexico; Demonstration of Technologies for Cleanup of St. Louis Airport Site 
(SLAPS); mailed in accordance with requests from British Nuclear Fuels Limited/Oak Ridge, and US DOE Grand Junction Mill Office, mailed 10 Feb 98

Mailing, BPF Newsletter, Volume 1, Issue 1, October 1997, Managing NORM in the Oil and Gas Industry, mailed to 56 attendees of the 4th International Petroleum Environmental Conference, 912 Sep 97, San Antonio TX, mailed Feb 98

Slide Presentation, Technology Development at BPF, Inc., Center for Citizen Initiatives Productivity Enhancement Program, Russian Delegation, 17 Feb 98, Duncanville TX

Mailing, BPF, Incorporated Corporate Profile, Jan 98; Is Your Site Safe? Treatment and On-Site Disposal of Radioactive Soils, Jan 98; Results from Bench-Scale Testing of a Mobile NORM Treatment and Disposal System; Results of Bench-Scale Testing of a Mobile On-Site NORM Treatment System in Texas and New Mexico; Demonstration of Technologies for Cleanup of St. Louis Airport Site (SLAPS); mailed in accordance with request from a West Texas waste management and disposal facility, mailed 6 Mar 98

Mailing, BPF, Incorporated Corporate Profile, Jan 98; Capabilities for the Treatment and On-site Disposal of Radioactive Soils; Is Your Site Safe? Treatment and On-Site Disposal of Radioactive Soils, Jan 98; Results from Bench-Scale Testing of a Mobile NORM Treatment and Disposal System; Results of Bench-Scale Testing of a Mobile On-Site NORM Treatment System in Texas and New Mexico; Demonstration of Technologies for Cleanup of St. Louis Airport Site (SLAPS); mailed to six government, national, and international industrial contacts, mailed 6 Mar 98

Mailing, BPF, Incorporated Corporate Profile, Jan 98; Capabilities for the Treatment and On-site Disposal of Radioactive Soils; Is Your Site Safe? Treatment and On-Site Disposal of Radioactive Soils, Jan 98; Results from Bench-Scale Testing of a Mobile NORM Treatment and Disposal System; Demonstration of Technologies for Cleanup of St. Louis Airport Site (SLAPS); mailed in accordance with request received from industrial contact in Santa Fe NM, mailed 19 Mar 98

Mailing, BPF, Incorporated Corporate Profile, Jan 98; Capabilities for the Treatment and On-site Disposal of Radioactive Soils; Is Your Site Safe? Treatment and On-Site Disposal of Radioactive Soils, Jan 98; Results from Bench-Scale Testing of a Mobile NORM Treatment and Disposal System; Demonstration of Technologies for Cleanup of St. Louis Airport Site (SLAPS); mailed in response to joint venture inquiry regarding Moab, Utah uranium mining site, mailed 24 Mar 98

Mailing, BPF, Incorporated Corporate Profile, Apr 98; Capabilities for the Treatment and Onsite Disposal of Radioactive Soils; Is Your Site Safe? Treatment and On-Site Disposal of Radioactive Soils, Jan 98; Results of Bench-Scale Testing of a Mobile On-Site NORM Treatment System in Texas and New Mexico; Demonstration of Technologies for Cleanup of St. Louis Airport Site (SLAPS); mailed to six industrial contractors regarding potential clean up of Rocky Flats Environmental Technology Site, mailed 27 Apr 98 
Mailing, BPF, Incorporated Corporate Profile, Apr 98; Capabilities for the Treatment and Onsite Disposal of Radioactive Soils; Is Your Site Safe? Treatment and On-Site Disposal of Radioactive Soils, Jan 98; Results of Bench-Scale Testing of a Mobile On-Site NORM Treatment System in Texas and New Mexico; Demonstration of Technologies for Cleanup of St. Louis Airport Site (SLAPS); mailed at request of West Texas oil and gas production company, mailed 4 May 98

Paper, The BPF Mobile NORM Treatment and Disposal System, 5th Annual International Petroleum Environmental Conference, 20-23 Oct 98, Albuquerque NM 